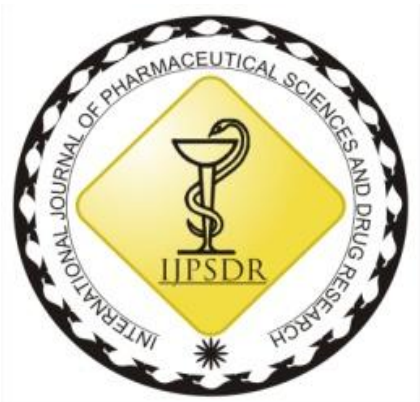

ISSN: 0975-248X

RESEARCH ARTICLE CODEN (USA): IJPSPP

$($ (c) EY-NG-SA

\title{
Antimicrobial Activity of Endophytic Fungi Isolated from Eryngium foetidum, an Ethnomedicinal Plant of Assam
}

\author{
Rajreepa Talukdar, Kumananda Tayung* \\ Mycology and Plant Pathology Laboratory, Department of Botany, Gauhati University, Guwahati-781014, Assam, India
}

Copyright (C) 2019 Rajreepa Talukdar et al. This is an open access article distributed under the terms of the Creative Commons AttributionNonCommercial-ShareAlike 4.0 International License which allows others to remix, tweak, and build upon the work non-commercially, as long as the author is credited and the new creations are licensed under the identical terms.

\begin{abstract}
Eyngium foetidum L. is a medicinal plant widely used by ethnic tribal communities of Assam as an alternative source of medicine for the treatment of various diseases. The present investigation was undertaken with an aim to isolate, identify and assess the antimicrobial activity of endophytic fungi associated with the healthy leaf tissues of $E$. foetidum. The endophytic fungi were isolated three different media, namely, Potato Dextrose Agar (PDA), Malt Extract Agar (MEA) and Water Agar (WA) media and from three different sites. Altogether, 84 endophytic fungal isolates were isolated from 150 segments of leaf tissues. Dominant endophytes were found to be fungi belonging to the genus Colletotrichum, followed by non-sporulating members grouped under mycelia sterilia. Other fungal genera that were isolated as endophytes were Scopulariopsis, Cladosporium, Stemphylium, Penicillium and Alternaria. The endophytic fungi thus isolated were studied for antimicrobial activity against some clinically significant human pathogenic test organisms. Ethyl acetate extracts of all endophytes exhibited antimicrobial activity by inhibiting at least one out of all the test pathogens. Amongst the isolated fungi, extracts obtained from three endophytes showed wide-spectrum activity against all the test organisms. The fungal endophytes were identified as Scopulariopsis sp., Penicillium sp. and a sterile isolate morphotype strain EF6. The study indicated that E. foetidum harbours a wide range of endophytes with antimicrobial properties and further detailed investigation of the compound present in them would lead to their potential therapeutic applications as a new source of medicine.
\end{abstract}

Keywords: Medicinal plant, Eryngium foetidum L., Endophytic fungi, Antimicrobial activity.

\begin{tabular}{l} 
DOI: 10.25004/IJPSDR.2019.110614 Int. J. Pharm. Sci. Drug Res. 2019; 11(6): $370-375$ \\
\hline *Corresponding author: Dr. Kumananda Tayung \\
Address: Mycology and Plant Pathology Laboratory, Department of Botany, Gauhati University, Guwahati-781014, Assam, India \\
Tel.: +91-8638067637 \\
E-mail $₫:$ kumanand@gauhati.ac.in \\
Relevant conflicts of interest/financial disclosures: The authors declare that the research was conducted in the absence of any commercial or \\
financial relationships that could be construed as a potential conflict of interest. \\
Received: 23 September, 2019; Revised: 04 November, 2019; Accepted: 09 November, 2019; Published: 30 November, 2019
\end{tabular}

\section{INTRODUCTION}

Medicinal plants have been used as potential sources of drugs since thousands of years both folk medicines as well as development of new modern and commercial medicines. In the recent times, these plants have been overexploited for obtaining plant-derived drugs in commercial levels. ${ }^{[1]}$ This commercialization demands higher amounts of raw plant biomass for production of even a small amount of potentially active drug. In addition to this, increased reports of developing resistance by most of the pathogenic fungi and bacteria against already available commercial drugs have become a serious cause of concern for the health services around the world. [2] As such, a thorough 
search for new and effectual antimicrobial agents is indispensable and this can only be done by exploring new niches and habitats. [3-4]

It has been found that all plants harbour a wide range of non-pathogenic microflora within their tissues which are known as endophytes. [5] Endophytic organisms, particularly, fungi residing in the medicinal plants are capable of biosynthesizing pharmacologically active secondary metabolites similar to those produced by the host plants. [6] These endophytic microorganisms are renowned producers of bioactive secondary metabolites like terpenoids, lactones, steroids, quinones, alkaloids, isocoumarins, phenylpropanoids, and phenols amongst many others. [7] Plant species used in traditional medicine has been reported to play a significant role for exploration of new bioactive strains of endophytic fungi. Another possibility might be that their beneficial qualities are a result of the metabolites produced by their endophytic microbes. ${ }^{[8-9]}$

Eryngium foetidum L. is a medicinal herb widely used alternative to modern medicine for treatment of a number of ailments. The leaves of this plant have been recognized to have anti-diarrhoeic, anti-helmenthic, anti-inflammatory, anti-convulsant, anti-microbial and anti-malarial properties and as well as found to be effective against snakebites, as wound-healers and also against infertility complications. It has been reported to be used against constipation, asthma and stomachache. [10-11] There are quite few reports on endophytic fungi of E. foetidum one of them being from Western Ghats and Biligirirangana hill of southern India. ${ }^{[12-13]}$ There is also report of novel bioactive compound Xylaropyrone obtained from the endophytic fungus, Xylaria feejensis isolated from E. foetidum of Thailand. [14] Such results exemplify that $E$. foetidum are colonized by endophytic fungi that can produce bioactive metabolites. Strobel and Daisy (2003) were of the opinion that areas with high biodiversity as well as high numbers of endemic plant species might be the most possible niches for endophytes with novel chemistry. ${ }^{[15]}$ Assam, which is amongst the states of North east India, is rich in medicinal plants. Eryngium foetidum L. is one such plant which is widely used by the ethnic tribal communities of Assam for treatment of various ailments. Therefore the present study was directed to isolate and identify endophytic fungi associated with healthy leaf tissues of $E$. foetidum with an aim to screen the isolates for antimicrobial activities against some clinically significant human test pathogens so that potent isolate could be studied further antimicrobial agents.

\section{MATERIALS AND METHODS}

\section{Sample collection}

Healthy plant samples of E. foetidum were collected from three different sites of Assam, namely, Amingaon $\left(26^{\circ} 11^{\prime} 5^{\prime \prime} \mathrm{N}\right.$ and $\left.91^{\circ} 40^{\prime} 9^{\prime \prime} \mathrm{E}\right)$, BaihataChariali ( $26^{\circ} 20^{\prime} 41^{\prime \prime} \mathrm{N}$ and $\left.91^{\circ} 43^{\prime} 35^{\prime \prime} \mathrm{E}\right)$ and Sonapur $\left(26^{\circ} 06^{\prime} 57.5^{\prime \prime} \mathrm{N}\right.$ and $\left.91^{\circ} 58^{\prime} 44.8^{\prime \prime} \mathrm{E}\right)$. From each site leaves of five individual healthy plants were selected randomly and collected in sterile polyethene bags. The collected plant species was identified by taxonomist via leaf and flower morphology and preserved in the Gauhati University Herbarium (accession no. 18539), Department of Botany. The samples were immediately brought to the laboratory and processed for isolation of endophytic fungi.

\section{Isolation of endophytic fungi}

Healthy leaves of E. foetidum were surface sterilized following Sushma et al. (2018) with slight modifications. They were sequentially dipped in $70 \%$ ethanol $(2 \mathrm{~min})$, followed by $0.5 \%$ sodium hypochlorite $(1 \mathrm{~min})$ then rinsed twice thoroughly with sterile distilled water (1-2 $\mathrm{min})$. The leaves were then allowed to surface dry under sterile conditions. Small circular fragments of leaves were punched out measuring $0.5 \mathrm{~mm}$ in diameter with the help of a sterile puncture. The surface sterilized fragments were then placed in three different mycological media namely, Potato Dextrose Agar (PDA), Malt Extract Agar (MEA) and Water Agar (WA) media supplemented with streptomycin sulphate $(50 \mu \mathrm{g} / \mathrm{ml})$ and incubated at $25 \pm 2{ }^{\circ} \mathrm{C}$ for 2 weeks. Fragments plated were observed once a day for the growth of endophytic fungi. Hyphal tips of fungi growing out of the surfaced sterilized leaf tissues were immediately transferred onto PDA slants and stored at $4^{\circ} \mathrm{C}$ for further study. The effectiveness of surface sterilization procedure was tested according to the method described by Schultz et al. (1998) by rubbing a surface sterilized leaf on a sterile PDA plate. Absence of any contaminant or fungal growth proved the efficacy of the protocol used. [16]

Identification of endophytic fungal isolates

The fungal isolates were identified based on their morphological and microscopically reproductive characters observed when grownon PDA using standard identification manuals. [17-19] The fungal isolates that failed to sporulate were categorized as Mycelia sterilia. Endophytic fungal isolates under Mycelia sterilia with distinct morphological features were designated as Morphotype.

Fungal diversity data analysis

The relative colonization frequency $(\mathrm{CF} \%)$ of endophytic species was calculated using the formula:

$$
\mathrm{CF} \%=\left(\mathrm{N}_{\text {col }} / \mathrm{N}_{\mathrm{t}}\right) \times 100
$$

Where, $N_{c o l}$ stands for the number of segments colonized by each endophytic fungal species, and $N_{t}$ stands for the total number of segments plated on media.

Dominant endophytic fungi recovered was calculated as percentage colony frequency divided by sum of percentage of colony frequency of all endophytes X 100. [20-21]

\section{Fungal cultivation and metabolites extraction}

Actively growing pure endophytic fungal isolates were cultivated in Potato Dextrose Broth (PDB) in $250 \mathrm{ml}$ Erlenmeyer flasks containing $100 \mathrm{ml}$ of the medium each. The fungal isolates were grown in BOD shaking incubator at $28^{\circ} \mathrm{C}$ for about 2 weeks with a periodic 
shaking of $120 \mathrm{rpm}$. Fungal culture was then filtered out through sterile whatman filter paper to remove the mycelial mats. The liquid broth was then collected and extracted with $100 \mathrm{ml}$ of ethyl acetate (EtOAc) each using a separating funnel after vigorously shaken for 10-15 min. Cell mass was discarded and the solvent so obtained was allowed to evaporate off using a rotary evaporator. Evaporation of the ethyl acetate yielded the crude extracts which was then dissolved in dimethyl sulphoxide (DMSO) and stored at $4^{\circ} \mathrm{C}$ for determination of antimicrobial activity.

\section{Determination of antimicrobial activity}

Antimicrobial activity of the crude metabolites was determined by agar cup diffusion method against some clinically significant human test pathogens. The test pathogens include one gram positive bacterium: Staphylococcus aureus (MTCC 737); two gram negative bacteria: Pseudomonas aeruginosa (MTCC 424), Escherichia coli(MTCC 443) and one pathogenic fungus Candida albicans (MTCC 227) all of which were procured from the Institute of Microbial Technology (IMTECH), Chandigarh, India. The bacterial test pathogens were cultivated on freshly prepared Nutrient Broth while the fungal test pathogen was cultured on Sabouraud's Dextrose Broth. For bacterial pathogens, nutrient agar plates were inoculated with $0.2 \mathrm{ml}$ of overnight grown culture containing $1.0 \times 10^{6}$ cells. Similarly, for fungal pathogen, Sabouraud's dextrose agar plate was inoculated with $0.2 \mathrm{ml}$ of culture containing $1.0 \times 10^{6}$ cells. The test organisms were evenly spread out on respective plates using a sterile cotton swab and agar cups were prepared on them using a sterile cork borer ( $7 \mathrm{~mm}$ in diameter).The agar cups were then filled in with $100 \mu \mathrm{L}$ of the culture filtrate of each endophytic fungus and incubated at $37 \pm 1^{\circ} \mathrm{C}$ for 24 hours for bacterial and at $28 \pm 1^{\circ} \mathrm{C}$ for 48 hours for fungal pathogens. The antimicrobial activity of the extracts was determined by appearance of clear zone of inhibition against the target organism around the agar cups. DMSO was used as the negative control whereas Streptomycin $(10 \mu \mathrm{g})$ and Fluconazole $(25 \mu \mathrm{g})$ were used as positive control.

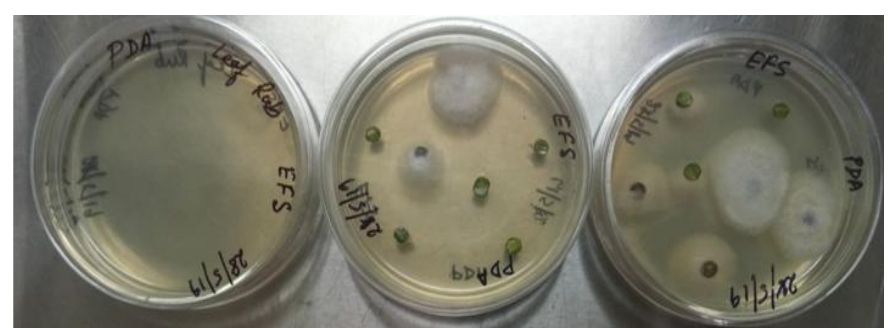

Fig. 1: Endophytic fungi growing out from surface sterilized leaf fragment of $E$. foetidum

\section{RESULTS}

Isolation and identification of endophytic fungi from E. foetidum

In the present study, endophytic fungi were isolated from healthy, symptomless leaves of E. foetidum from three different sites and in different media. Out of the
150 leaf segments plated, a total number of 84 endophytic fungal isolates were recovered belonging to species under different genera. The highest recovery of endophytes was obtained in WA medium (28.67\%), followed by MEA (16.67\%) and the least was in PDA medium (10.67\%) [Table 1].

Table 1: Endophytes recovered from E. foetidum leaf on different media from various sites.

\begin{tabular}{|c|c|c|c|c|c|c|}
\hline \multirow[t]{2}{*}{ Sample } & \multirow[t]{2}{*}{ Media } & \multicolumn{3}{|c|}{$\begin{array}{c}\text { No. of colonies } \\
\text { recovered per } \\
\text { location }\end{array}$} & \multirow{2}{*}{$\begin{array}{l}\text { Total no. of } \\
\text { fungal } \\
\text { colonies } \\
\text { recovered/150 } \\
\text { segments }\end{array}$} & \multirow{2}{*}{$\begin{array}{c}\% \text { of } \\
\text { Recovery }\end{array}$} \\
\hline & & AN & BH & SN & & \\
\hline \multirow[t]{4}{*}{ Leaf } & PDA & 7 & 5 & 12 & 16 & 10.67 \\
\hline & MEA & 5 & 9 & 14 & 25 & 16.67 \\
\hline & WA & 4 & 9 & 17 & 43 & 28.67 \\
\hline & $\begin{array}{c}\text { Total } \\
\text { isolates }\end{array}$ & 16 & 25 & 43 & 84 & 56.01 \\
\hline
\end{tabular}

$\overline{\mathrm{PDA}}=$ Potato Dextrose Agar; MEA=Malt Extract Agar; WA=Water; $\mathrm{AN}=$ Amingaon, $\mathrm{BH}=$ Baihata, $\mathrm{SN}=$ Sonapur.

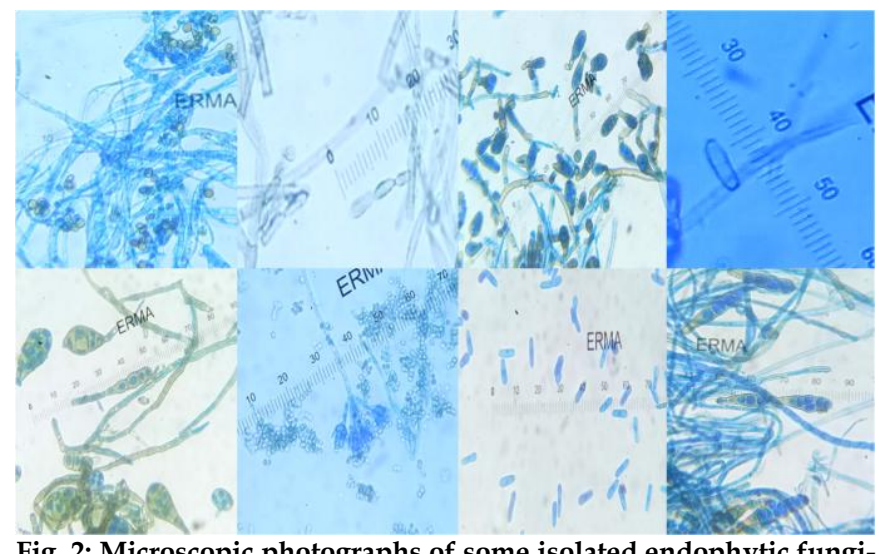

Fig. 2: Microscopic photographs of some isolated endophytic fungia) Scopulariopsis sp., b)Cladosporium macrocarpum, c) Alternaria sp., d) Cladosporium fulvum, e) Stemphylium sp. 1, f) Penicillium sp., g) Colletotrichum sp., h) Stemphylium sp. 2 (under 40x)

The total colonizing frequency $(\mathrm{CF} \%)$ of endophytic fungi in healthy leaf tissues of E. foetidum was found to be $56 \%$ out of which the genus Colletotrichum showed the highest colonization frequency $(32.67 \%)$, followed by the non-sporulating isolates categories as morphotypes $(15.33 \%)$. The other endophytic fungal isolates were Scopulariopsis sp. $(0.67 \%)$, Cladosporium macrocarpum, Cladosporium fulvum (0.67\%), Stemphylium sp. (4\%), Penicillium sp. (0.67\%) and Alternaria sp. $(0.67 \%)$ [Table 2]. The commonly isolated species from all the sampling sites was found to befungi belonging to genera Colletotrichum. Amongst the genera of Colletotrichum, the most dominant isolate was found to Colletotrichum sp.10 with a colonization frequency of $11.33 \%$. The non-sporulation fungal groups which were designated as morphotypes did not produce any sexual or asexual propagules both on synthetic or host extract amended media. Among them, morphotype sp.1 showed the highest colonization frequency of $9.33 \%$. Maximum number of isolates were recovered from Sonapur (43), followed by Jalukbari (25) and the least was from Amingaon (16). 
Rajreepa Talukdar et al. / Antimicrobial Activity of Endophytic Fungi Isolated from Eryngium foetidum....

Table 2: Composition of endophytic fungi in healthy leaf tissues of E. foetidum isolated from three different sites of Assam.

\begin{tabular}{|c|c|c|c|c|c|c|}
\hline \multirow{2}{*}{ Endophytic fungi } & \multicolumn{3}{|c|}{ Locations } & \multirow{2}{*}{ Total isolates $/ 150$ fragments } & \multirow{2}{*}{ CF $(\%)$} & \multirow{2}{*}{ Frequency of dominant endophytes (\%) } \\
\hline & AN & BH & SN & & & \\
\hline Scopulariopsis sp. & 1 & -- & -- & 1 & 0.67 & 1.19 \\
\hline Cladosporium macrocarpum & 4 & -- & -- & 4 & 2.67 & 4.76 \\
\hline Cladosporium fulvum & 1 & -- & -- & 1 & 0.67 & 1.19 \\
\hline Stemphylium sp.1 & -- & 4 & 1 & 5 & 3.33 & 5.94 \\
\hline Stemphyliums p. 2 & -- & 1 & -- & 1 & 0.67 & 1.19 \\
\hline Penicillium sp. & -- & 1 & -- & 1 & 0.67 & 1.19 \\
\hline Alternaria sp.1 & -- & 1 & -- & 1 & 0.67 & 1.19 \\
\hline Alternaria sp. 2 & -- & 1 & -- & 1 & 0.67 & 1.19 \\
\hline Colletotrichum sp.1 & -- & 1 & -- & 1 & 0.67 & 1.19 \\
\hline Colletotrichum sp.2 & -- & 1 & -- & 1 & 0.67 & 1.19 \\
\hline Colletotrichum sp.3 & -- & 1 & -- & 1 & 0.67 & 1.19 \\
\hline Colletotrichum sp.4 & -- & 1 & -- & 1 & 0.67 & 1.19 \\
\hline Colletotrichum sp.5 & -- & 1 & -- & 1 & 0.67 & 1.19 \\
\hline Colletotrichum sp.6 & -- & 4 & -- & 4 & 2.67 & 4.76 \\
\hline Colletotrichum sp.7 & -- & 2 & -- & 2 & 1.33 & 2.37 \\
\hline Colletotrichum sp. 8 & -- & -- & 2 & 2 & 1.33 & 2.37 \\
\hline Colletotrichum sp.9 & -- & -- & 8 & 8 & 5.33 & 9.52 \\
\hline Colletotrichum sp.10 & -- & -- & 17 & 17 & 11.33 & 20.23 \\
\hline Colletotrichum sp.11 & -- & -- & 5 & 5 & 3.33 & 5.94 \\
\hline Colletotrichum sp.12 & -- & -- & 5 & 5 & 3.33 & 5.94 \\
\hline Morphotype sp.1 & 10 & 4 & -- & 14 & 9.33 & 16.66 \\
\hline Morphotype sp.2 & -- & 2 & -- & 2 & 1.33 & 2.37 \\
\hline Morphotype sp. 3 & -- & - & 2 & 2 & 1.33 & 2.37 \\
\hline Morphotype sp.4 & -- & -- & 1 & 1 & 0.67 & 1.19 \\
\hline Morphotype sp.5 & -- & -- & 1 & 1 & 0.67 & 1.19 \\
\hline Morphotype sp.6 & -- & -- & 1 & 1 & 0.67 & 1.19 \\
\hline Total no. of isolates & 16 & 25 & 43 & 84 & 56.01 & \\
\hline
\end{tabular}

* $\mathrm{CF}=$ Colonization Frequency; $\mathrm{AN}=$ Amingaon, $\mathrm{BH}=$ Baihata , $\mathrm{SN}=$ Sonapur

Table 3: Antimicrobial activity of endophytic fungi isolated from E. foetidum against pathogenic test organisms.

\begin{tabular}{|c|c|c|c|c|c|}
\hline Isolate code & Endophytic fungi & Candida albicans & Staphylococcus aureus & Escherichia coli & Pseudomonas aeruginoso \\
\hline EF1 & Scopulariopsis sp. & ++ & ++ & ++ & ++ \\
\hline EF2 & Cladosporium macrocarpum & ++ & + & + & + \\
\hline EF12 & Cladosporium fulvum & ++ & + & ++ & + \\
\hline EFB4 & Stemphylium sp.1 & +++ & + & + & + \\
\hline EFB5 & Stemphylium sp.2 & ++ & ++ & + & + \\
\hline EFB9 & Penicillium sp. & +++ & +++ & ++ & +++ \\
\hline EFB16 & Alternaria sp.1 & ++ & + & + & + \\
\hline EFB17 & Alternaria sp.2 & ++ & + & + & + \\
\hline EFB1 & Colletotrichum sp.1 & + & + & + & + \\
\hline EFB2 & Colletotrichum sp.2 & ++ & + & + & + \\
\hline EFB3 & Colletotrichum sp.3 & ++ & + & + & + \\
\hline EFB14 & Colletotrichum sp.4 & ++ & + & + & + \\
\hline EFB15 & Colletotrichum sp.5 & ++ & + & ++ & + \\
\hline EFB18 & Colletotrichum sp.6 & ++ & + & ++ & + \\
\hline EFB22 & Colletotrichum sp.7 & ++ & + & + & + \\
\hline EFS1 & Colletotrichum sp.8 & ++ & + & + & ++ \\
\hline EFS2 & Colletotrichum sp.9 & ++ & + & + & + \\
\hline EFS4 & Colletotrichum sp.10 & ++ & + & ++ & + \\
\hline EFS14 & Colletotrichum sp.11 & + & -- & + & + \\
\hline EFS28 & Colletotrichum sp.12 & ++ & -- & + & + \\
\hline EF6 & Morphotype sp.1 & ++ & +++ & ++ & ++ \\
\hline EFB6 & Morphotype sp.2 & ++ & -- & + & + \\
\hline EFS13 & Morphotype sp.3 & + & + & + & -- \\
\hline EFS15 & Morphotype sp.4 & + & + & -- & + \\
\hline EFS35 & Morphotype sp.5 & + & ++ & -- & + \\
\hline EFS41 & Morphotype sp.6 & + & -- & + & -- \\
\hline
\end{tabular}

"--" no inhibition; "+"> $10 \mathrm{~mm} ; "$ ++"> $15 \mathrm{~mm} ; "$ "++" > $20 \mathrm{~mm}$.

\section{Antimicrobial activity of endophytic fungi}

The isolates were screened for antimicrobial activity against some clinically important pathogenic human test organisms. The result showed that all of the fungal isolates displayed antimicrobial activity by inhibiting at least one of the test pathogens (Table 3). It was also observed that most of the isolates were effective in inhibiting all the test pathogens considered. However, comparatively the isolates showed higher antifungal activity against Candida albicans than the bacterial pathogens. Amongst the isolates three endophytic fungi showed considerable antimicrobial activity by 
inhibiting three bacterial pathogens and one pathogenic fungus. The isolates were identified as Scopulariopsis sp., Penicillium sp. and non-sporulating isolate morphotype sp.1 (strain EF6). The ethyl acetate extracts of these three fungi showed very effective inhibition against all the four test pathogens by agar diffusion assay (Fig. $3 \& 4$ ).

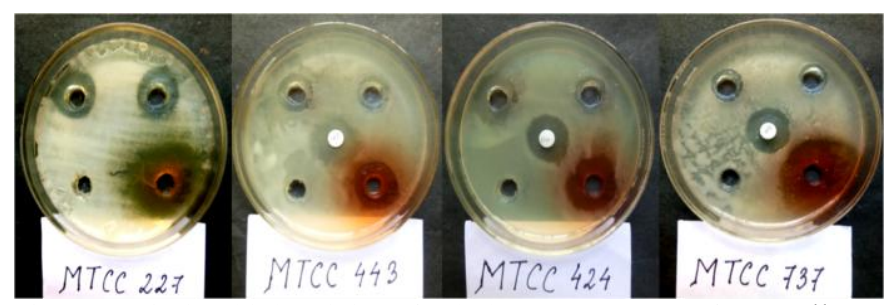

Fig. 3: Antimicrobial activity of ethyl acetate extract of Penicillium sp. against test pathogens

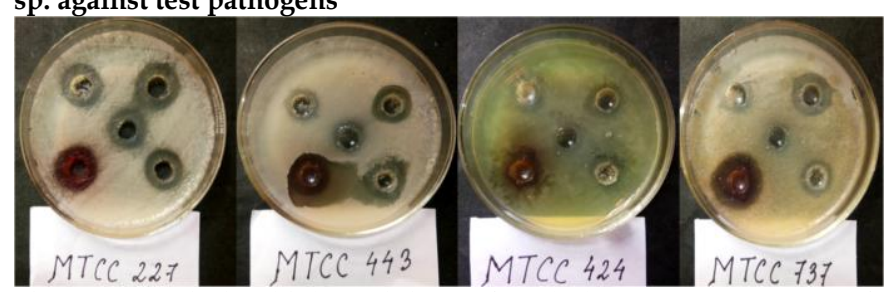

Fig. 4: Antimicrobial activity of ethyl acetate extract of Scopulariopsis sp. and non-sporulating isolate, Morphotype sp.1 against test pathogens

\section{DISCUSSION}

Endophytic fungi are ubiquitous in nature and known to be distributed naturally in both temperate and tropical regions. Reports suggest the presence of numerous endophytic fungi within medicinal plants that are involved in the co-production of active metabolites. ${ }^{[22]}$ In the present study, endophytic fungi assemblages of E. foetidum, an ethno-medicinal plant of Assam in North-East India was investigated for antimicrobial metabolites. A total of 84 endophytic fungal strains were isolated from surface sterilized leaf fragments of $E$. foetidum on three different mycological media (PDA, MEA and WA).The highest percentage recovery of endophytes from the leaves of this was observed from WA media $(28.67 \%)$. Similar recovery of endophytes from $E$. foetidum was also observed from WA media in earlier works where isolation of endophytes was done from various parts of the plant from the Western Ghats of India. ${ }^{[12]}$ However there are no reports of endophytes being isolated from the leaves of this plant, which is the mostly used part in ethnic pharmacology in the North East India. Amongst the sites, Sonapur an unpolluted area harboured maximum endophytes while least was obtained from Amingaon which is an area with rapid industrial development. The decrease in the abundance and diversity of fungal communities might be the effect of toxic metals air pollutants as also reported in Pine needles. [23] The endophytes consisted of fungi belonging to different genera Colletotrichum, Scopulariopsis, Cladosporium, Stemphylium, Penicillium, Alternaria and non-sporulating fungi categorized as mycelia sterilia and isolates with distinct cultural morphology were conventionally classified as morphotypes. Alternaria was found to be isolated as endophytic fungi from $E$. foetidum in Biligirirangana hill, India. ${ }^{[13]}$ The result showed that the genus Colletotrichum was isolated from two of the three study sites while non-sporulating fungal genera were mostly isolated from Jalukbari site. In various instances, the genus Colletotrichumhas been reported as dominant endophytic fungi from several medicinal plants species. [24-26] However, this is the first report from E. foetidum leaf tissues. The variation of endophytic colonization frequency among the sites might due to various environmental factors. Many workers were of the opinion that endophytic fungal communities changes through time and space and is influenced by climatic and environmental conditions. [27-28]

Another important aspect of studies on endophytic microbes, especially, fungi is their latent ability to produce a large array of bioactive compounds that can defend the plant against various pathogenic organisms. [15, 29] For instance, natural compounds synthesized by endophytic fungi have been reported to have inhibitory effect against varied types of animal and plant pathogens. [30-31] Similar was the case in the typical example of taxol, an anticancer agent produced by Taxus brevifolia and its associated endophyte, Taxomyces andreanae. ${ }^{[32]}$ Reports are found to propose that the medicinal properties of a plant might be the result of the capacity of its associated endophytes to produce biologically active secondary metabolites. [33] As such, the isolation and identification of endophytic mycobiota is necessary to have an insight to their bioactive potential. In the present study, a total of 25 strains out of $84(29.76 \%)$ showed antimicrobial activity most of which (18 out of 25) showed wide spectrum activity. The three most potent isolates that effectively inhibited the test pathogens were Scopulariopsis sp. (strain EF1), Penicillium sp. (strain EFB9) and morphotype sp.1 (strain EF6). However, amongst the isolates, ethyl acetate extract obtained from Penicillium extract was found to be most effective in inhibiting all the four test pathogens. Reports suggest that various parameters like difference in incubation temperature, changes in composition of media and degree of aeration influence the amount and type of compound produced by an endophytic fungus. [34] In addition, these parameters might either increase or decrease the production of bioactive compounds by the particular endophytic fungi. For this reason, further tests are needed to evaluate the biological activity of the strains that showed inhibition during the fermentation assay. Moreover, our interpretation clearly specifies that endophytic fungi from leaves of E. foetidum have pharmaceutical potential as they might produce antimicrobial compounds. Also, the therapeutic properties of this plant might be an outcome of the capacity of endophytic microorganisms to produce biologically active secondary metabolites. Advanced 
studies into this area is now essential to identify the active compounds produced in order to discover novel drugs with antimicrobial activity.

\section{ACKNOWLEDGEMENT}

We thank the Dept. of Botany, Gauhati University, Assam, India for providing laboratory facilities to carry out this work.

\section{REFERENCES}

1. Pan SY, Zhou SF, Gao SH, Yu ZL, Zhang SF, Tang M, Sun JN, Ma DL, Han Y, Fong WF, Ko KM. New Perspectives on How to Discover Drugs from Herbal Medicines: CAM's Outstanding Contribution to Modern Therapeutics. Evid Based Complement Alternat Med. 2013; 627375.

2. Aksoy DY, Unal S. New antimicrobial agents for the treatment of Gram-positive bacterial infections. Clin Microbiol Infect. 2008; 14: 411-420.

3. Xing YM, Chen J, Cui JL, Chen XM, Guo SX. Antimicrobial activity and biodiversity of endophytic fungi in Dendrobium devonianum and Dendrobium thyrsiflorum from Vietman. Curr Microbiol. 2011; 62: 1218-1224.

4. Zhao J, Shan T, Mou Y, Zhou L Plant derived bioactive compounds produced by endophytic fungi. Mini reviews in medicinal chemistry. 2011a; 11: 159-168.

5. Rodriguez RJ, White JF, Arnold AE, Redman RS. Fungal endophytes: diversity and functional roles. New Phytologist. 2009; 182:314-330.

6. Venieraki A, Dimou M, Katinakis P. Endophytic fungi residing in medicinal plants have the ability to produce the same or similar pharmacologically active secondary metabolites as their hosts Hellenic Plant Protection Journal. 2017; 10: 51-66.

7. Deshmukh SK, Verekar SA, Bhave SV. Endophytic fungi: a reservoir of antibacterials. Front. Microbiol. 2014; 5:715.

8. Kaul S, Gupta S, Ahmed M, Dhar MK. Endophytic fungi from medicinal plants: A treasure hunt for bioactive metabolites. Phytochem. Rev. 2012; 11: 487-505.

9. Kusari S, Pandey SP, Spitellera M. Untapped mutualistic paradigms linking host plant and endophytic fungal production of similar bioactive secondary metabolites. Phytochemistry. 2013; 91: 81-87.

10. Garcia MD, Saenz MT, Gomez MA, Fernandez MA. Topical anti-inflammatory activity of phytosterols isolated from Eryngium foetidum on chronic and acute animal models. Phytother Res. 1999;13: 78-80.

11. Paul JHA, Seaforth CE, Tikasingh T. Eryngium foetidum L.: A review. Fitotherapia. 2011; 82: 302-308.

12. Nalini MS, Ningaraju S, Prakash HS. Endophytic Fungal Diversity in Medicinal Plants of Western Ghats, India Hindawi Publishing Corporation International Journal of Biodiversity. 2014:1-9.

13. Sushma KS, Jayashankar M, Vinu AK, Saeed MA 2018 Identification of endophytic fungi from the medicinal plants of Biligirirangana hill, Karnataka. Journal of Applied and Natural Science. 2018; 10(4): 1156 -1161

14. Siriwach R, Kinoshita H, Kitani S, Igarashi $Y$, Pansuksan K, Panbangred $W$, Nihira T. Xylaropyrone, a new $\gamma$-pyrone from the endophytic fungus Xylaria feejeensis MU18. The Journal of Antibiotics. 2011; 64: 217-219.

15. Strobel GA, Daisy B. Bioprospecting for Microbial Endophytes and Their Natural Products. Microbiol Mol Biol Rev. 2003; 67: 491-502.
16. Schulz B, Guske S, Dammann U., Boyle C. Endophyte-host interactions. II. Defining symbiosis of the endophyte-host interaction. Symbiosis. 1998; 25: 213-227.

17. Gilman JC. A Manual of Soil Fungi. $2^{\text {nd }}$ Ed. Iowa State College Press. 1971.

18. Barnett HL, Hunter BB. Illustrated Genera of Imperfect Fungi. APS Press. 1996.

19. Damm U, Johnston PR, Weir BS. The Colletotrichum gloeosporioides species complex. Studies in Mycology. 2012; 73: 115-180.

20. Hata K, Futai K. Endophytic fungi associated with healthy pine needles and needles infested by the pine needle gall midge, Thecodiplosis japonensis. Canadian Journal of Botany. 1995; 73:384-390.

21. Tayung K, Jha DK. Antimicrobial evaluation of some fungal endophytes isolated from bark of Himalayan yew. World J of Agric Sciences. 2006; 2: 489-494.

22. Alvin A, Miller KI, Neilan BA. Exploring the potential of endophytes from medicinal plants as sources of antimycobacterial compounds. Microbiol Res. 2014; 169(7-8): 483-495.

23. Helander ML, 1995 Responses of pine needle endophytes to air pollution New Phytol. (1995), 131, 223-229

24. Thalavaipandian A. Diversity of fungal endophytes in medicinal plants of Courtallam hills, Western Ghats, India. Mycosphere. 2011; 2: 575-582.

25. Siqueira VM, Conti R, Araujo JM, Souza-Motta CM. Endophytic fungi from the medicinal plant Lippia sidoides Cham. and their antimicrobial activity. Symbiosis. 2011; 53:89-95

26. John R, Mathew L. Endophytic fungal assemblage in Achyranthes aspera Linn. revealed by internal transcribed spacer region of nuclear ribosomal RNA genes. 3 Biotech. 2017; 7(2):109.

27. Fisher PJ, Petrini O, Petrini LE, Sutton BC. Fungal endophytes from the leaves and twigs of Quercus ilex L. from England, Majorca and Switzerland. New Phytologist. 1994; 127: 133-137.

28. Gao XX, Zhou H, Xu DY, Yu CH, Chen YQ, Qu LH. High diversity of endophytic fungi from the pharmaceutical plant, Heterosmilax japonica Kunth revealed by cultivationindependent approach. FEMS Microbiology Letters. 2005; 249: 255-266.

29. Tan RX, Zou WX. Endophytes: A rich source of functional metabolites. Nat. Prod. Rep. 2001; 18: 448-459.

30. Gunatilaka AAL. Natural products from plant-associated microorganisms: distribution, structural diversity, bioactivity and implications of their occurrence. J. Nat. Prod. 2009; 69: 509-526.

31. Zhao J, Zhou L, Wang J, Shan T, Lingyun Z, Liu X, Gao L. Endophytic fungi for producing bioactive compounds originally from their host plants. Current Research, Technology and Education Topics in Applied Microbiology and Microbial Biotechnology. 2010; 1.

32. Stierle A, Strobel G, Stierle D. Taxol and taxane production by Taxomyces andreanae, an endophytic fungus of Pacific yew. Science. 1993; 260: 214

33. Kusari P, Kusari S, Spiteller M, Kayser O. Endophytic fungi harbored in Cannabis sativa L.: diversity and potential as biocontrol agents against host plant-specific phytopathogens. Fungal Divers. 2013; 60:137-151.

34. Strobel G, Daisy B, Castillo U, Harper J. Natural products from endophytic microorganisms. Journal of Natural Products. 2004; 67: 257-268. 